\title{
Evaluation of Monthly Groundwater Level in Bursa, Turkey
}

\author{
Regaip Fidan $^{1 *}$ (iD, Egemen $\operatorname{Aras}^{2}$ iD, Babak Vaheddoost ${ }^{2}$ (iD) \\ 1 Bursa Regional Directorate of the State Hydraulic Works (DSi),Bursa, Turkey \\ ${ }^{2}$ Bursa Technical University, Faculty of Engineering and Natural Sciences, Civil Engineering Department, Ylldirlm,Bursa,Turkey
}

\begin{abstract}
Cite this paper as:
Fidan, R., Aras, E., Vaheddoost, B. (2019). Evaluation of Monthly Groundwater Level in Bursa, Turkey. Journal of Innovative Science and Engineering. 3(1): 38-46
\end{abstract}

*Corresponding author: Regaip Fidan E-mail: regaipfidan@gmail.com

Received Date: 03/05/2019

Accepted Date: $24 / 06 / 2019$

(C) Copyright 2019 by

Bursa Technical University. Available online at http://jise.btu.edu.tr/

\section{(c) (i) (9)}

The works published in Journal of Innovative Science and Engineering (JISE) are licensed under a Creative Commons Attribution-NonCommercial 4.0 International License.

\begin{abstract}
As an alternative resource to the surface water, groundwater is a vital resource that has been on the interest of many recent studies. Hence, the evaluation of the groundwater potential, its properties, and its availability needs specific dedication. In this study, monthly groundwater level time series at 9 observation wells scattered aligned with Mount Uludağ in Bursa are used. A 12-year period starting from January 2007 to October 2018 is taken into analysis and several statistical properties of the groundwater level time series are projected on maps. These statistical values are mean, coefficient of skewness, coefficient of kurtosis, coefficient of variation, and correlation coefficient. Results indicate that there is a high potential in the groundwater flow towards Yeniceabat. A strong linear correlation between groundwater levels in wells was observed which shows the potential connectivity between aquifers in the region. In addition, the groundwater levels located at the north show irregular patterns, probably due to water withdrawal for agriculture purposes.
\end{abstract}

Keywords: Bursa, evaluation, groundwater level 


\section{Introduction}

The groundwater level is a major resource of fresh water which can be found all around the world. According to UNESCO, in 2025 almost 1.8 billion people would have less access to water around the World [1;2]. In addition, water pollution, as well as a $40 \%$ increase in water demand in more than 80 countries caused several crises in the last decades [3]. It is an indication of, how fragile our society can be through water shortage.

Groundwater resources are usually captured either in confined or unconfined aquifers. They are usually recharged once the excess water from precipitation, snowmelt, or streamflow infiltrates to the ground and continues to percolation deep in the soil until it reaches to an impermeable layer. This phenomenon has a complex hydrology of which, several studies showed that there are a lot of unknowns associated with it. Statistics show that, annual renewable water of Turkey is about 110 billion $\mathrm{m}^{3} /$ year considering $98 \times 10^{9} \mathrm{~m}^{3} /$ year of surface water, and $12 \times 10^{9} \mathrm{~m}^{3} /$ year of groundwater [4]. Thereby, it is important to evaluate the present situation and foresee the possible problems associated with the groundwater.

In this respect, Imbach investigated the deep groundwater circulation of Bursa region [5]. It was concluded that shallow groundwater interaction with other water resources, energy loss of the water body due to heat conduction, and gas interaction of the mantle can be considered as the dominant processes that affect deep groundwater. Balderer et al. studied isotopes and chemical in Bursa and Adapazari at the northwest of Turkey [6]. Gundogdu and Guney investigated spatial variations in groundwater level around Bursa district, by using universal Kriging method [7]. It was concluded that the rational quadratic semi-variogram method shows better performance in advance. Adamowski and Chan also used wavelet-neural network modeling techniques in forecasting groundwater level at Bursa region [8]. It was found that these methods are effective in forecasting groundwater level.

Since the previous literature related to the groundwater in the Bursa region was mostly focused on the geological behavior of the aquifers, it was found beneficial to evaluate the present situation of the groundwater and its hydrology in a statistical manner. In this respect, the methods used by Vaheddoost and Aksoy were used to evaluate the situation [9]. This study evaluated the interaction of groundwater level with the lake water level at Lake Urmia basin. Several groundwater wells were selected and statistical behavior of them was investigated. It was concluded that the groundwater has a great potential to discharge into the lake whilst over-consumption of this resource can lead to great disaster with no return. Similarly, Hao et al. evaluated the correlation between groundwater declines and anthropogenic activities in Bashang, China [10]. It was concluded that tourism and agricultural developments are the main factors in increasing the demand in urban- and rural water consumption.

In this respect, the aim of this study is to (i) investigate the present situation of the groundwater resources in Bursa, and (ii) search for the possible irregularities and potential anomalies in the groundwater level time series.. 


\section{Methods}

\subsection{Study Area}

The study was carried out in Bursa city, which is located at the northwest of Turkey (Figure 1). Bursa as the $4^{\text {th }}$ major city in Turkey, has the largest groundwater potential in the region. It has more than 18 industrial zones, and acres of farmland which makes it a major destination for a lot of investment. Mount Uludağ with $2543 \mathrm{~m}$ above mean sea level, together with Ulubat and İznik lakes are shaping the major features of the area. Bursa is shared between three watersheds of Marmara, Susurluk and Sakarya. Based on Köppen-Geiger climate classification map, it is classified with Csa, and $C s b$ climate regime; in which $C$ stands for warm temperature, $S$ is the indication of dry summer, whilst $a$, and $b$ respectively stands for hot and warm summer (http://koeppen-geiger.vu-wien.ac.at/). Although no water shortage was reported in the region, population growth and subsequent rise in water demand are expected to be on the major concern of the decision makers and government. Thereby, it is important to be aware of the current groundwater situation of the region which is the main motivation for this study.

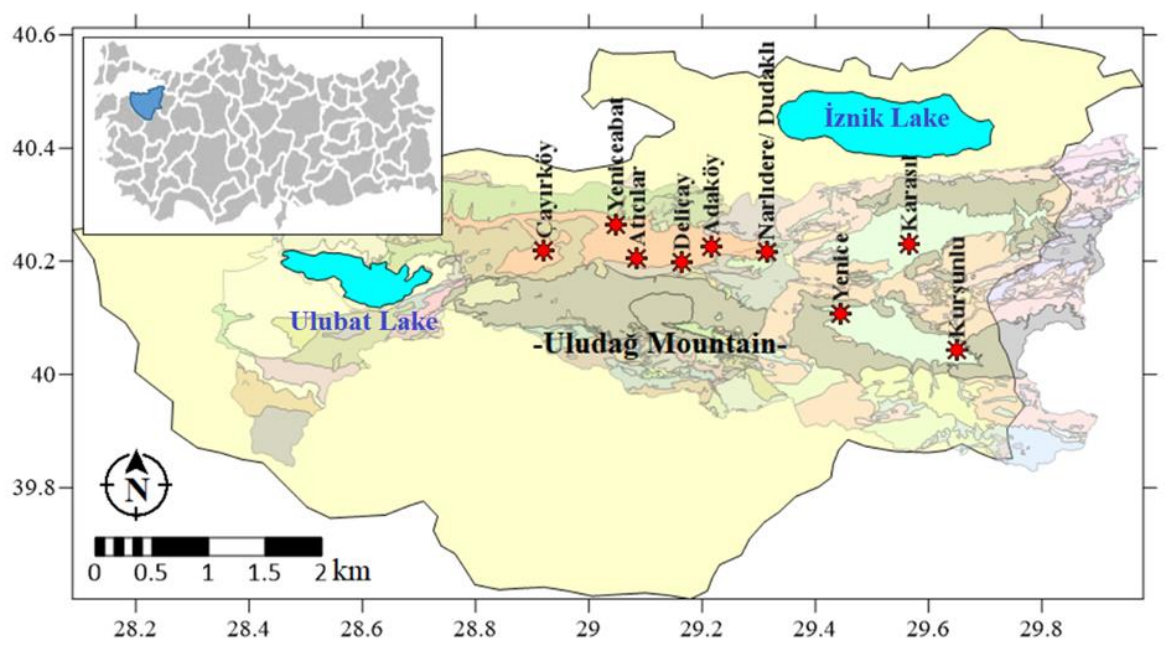

Figure 1. Location of the selected wells at Bursa province in Turkey

\subsection{Method Used}

Data used in this study was provided by Bursa Regional Directorate of the State Hydraulic Works (i.e. State Hydraulic Works, DSI) in monthly format between January 2007 to October 2018. Particularly, monthly groundwater level time series at 9 observation wells at İnegöl, Yenişehir, Yıldırım, Gürsu, Nilüfer, and Osmangazi districts were used (Figure 1). These wells are located in Narlıdere (Na), Deliçay (De), Adaköy (Ad), Atıcılar (At), Yeniceabat (Yet), Çayırköy $(\mathrm{Ca})$, Kurşunlu $(\mathrm{Ku})$, Yenice (Ye), and Karasıl (Ka). Then, the statistical properties of the groundwater level at wells are used to evaluate the spatial changes in the $n$-th moment of the distribution using

$$
\mu^{n}=\int_{-\infty}^{+\infty}(x-c)^{n} f(x) d x
$$


where $n$-th moment, $\mu^{n}$, was calculated using variable $x$ around the allocated value of the interest, $c$. Therefore, the mean groundwater level $(\mathrm{GWL})$, coefficient of skewness $\left(C_{s}\right)$, coefficient of kurtosis $\left(C_{k}\right)$, and the correlation coefficient $\left(C_{c}\right)$ between groundwater level time series are calculated.

It was also found useful to project the obtained results on the maps by means of SURFER software using Kriging interpolation method. This approach would be very beneficial in the evaluation and understanding of the groundwater level properties as well as the potential flow direction in the region.

\section{Results and Discussion}

\subsection{Flow Direction and Mean Monthly Groundwater Level}

Mean groundwater level at selected wells is obtained as the first moment of the distribution using Equation 1 to define the potential groundwater flow direction in the region (Figure 2). Monthly changes in the mean groundwater level are also provided in Table 1, which shows similar patterns. In all stations except in Kurşunlu (Ku), the lowest monthly groundwater level is observed in September as the last month of the water year. However, groundwater time series at Kurşunlu experiences the lowest groundwater levels at January which may be related to the anthropogenic disturbance in the groundwater of the rural area. It is obvious that the groundwater, due to the hydraulic gradient, potentially flows through the north, at Yenicabat (Yet). Perfectly aligned with the natural topography of the region, it is also possible that the flow direction is affected by the snow melt at the high altitudes (i.e. Mount Uludağ). In west coasts, however, particularly at Çayırköy $(\mathrm{Ca})$, the pattern shifts toward the east and the groundwater flow direction changes. This may be due to the underground flow which is recharged by Ulubat lake. Similar patterns also observed for Karasil (Ka) station, which has an easterly flow direction. Several changes are also observed at the Yenice (Ye), Kurşunlu (Ku) and Karas1 (Ka) which are mostly parallel with each other. Based on results given in Table 1, an increase in groundwater level at Narlıdere (Na), Deliçay (De), Kurşunlu (Ku), and Yenice (Ye) wells are observed in July, whilst other wells experience a decreasing pattern in earlier months. This is thought to be due to the initiation of the irrigation season at the region.

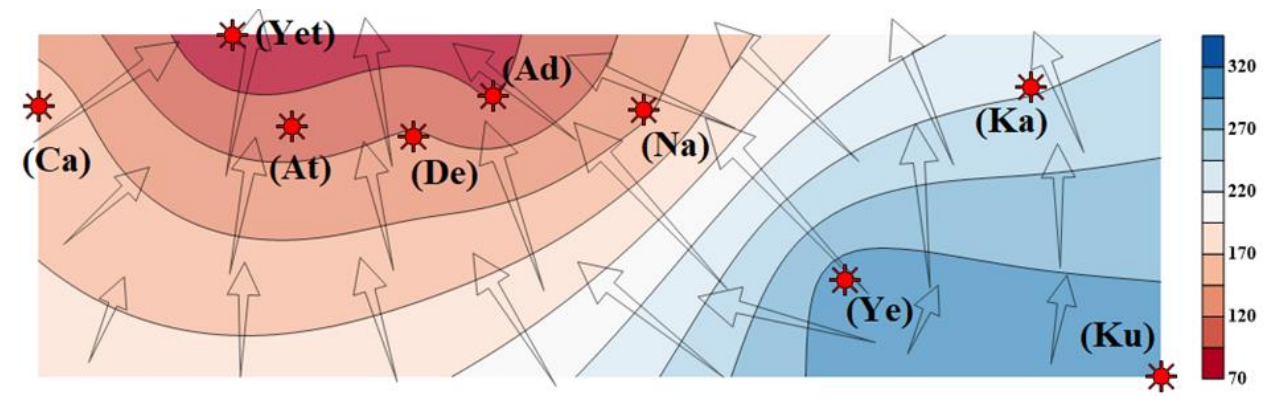

Figure 2. The potential directions of groundwater flow (Scale bar show the mean groundwater level at the wells measured as meters above mean sea level) 
Table 1. Monthly mean groundwater level (GWL) in the observation wells

\begin{tabular}{lccccccccc}
\hline & Narlıdere & Deliçay & Adaköy & Atıcılar & Yeniceabat & Çayırköy & Kurşunlu & Yenice & Karasıl \\
\hline January & 139,56 & 120,81 & 93,80 & 107,41 & 73,53 & 161,57 & 307,81 & 308,99 & 242,54 \\
February & 139,53 & 121,58 & 94,00 & 107,50 & 71,61 & 161,69 & 308,62 & 309,17 & 242,82 \\
March & 139,28 & 121,46 & 94,03 & 107,14 & 72,07 & 161,82 & 309,30 & 309,27 & 242,85 \\
April & 139,95 & 121,39 & 94,03 & 107,14 & 72,94 & 161,59 & 310,17 & 309,59 & 243,15 \\
May & 141,05 & 125,29 & 94,00 & 107,18 & 72,99 & 161,29 & 310,56 & 309,68 & 242,96 \\
June & 141,58 & 129,01 & 93,89 & 107,02 & 72,35 & 160,70 & 310,68 & 310,02 & 242,98 \\
July & 142,23 & 129,80 & 93,09 & 107,11 & 71,76 & 160,29 & 311,18 & 310,55 & 242,72 \\
August & 139,33 & 126,19 & 92,66 & 106,42 & 68,96 & 159,32 & 309,67 & 309,35 & 241,14 \\
September & 138,17 & 123,94 & 92,04 & 106,65 & 68,81 & 159,20 & 308,96 & 309,23 & 241,22 \\
October & 137,81 & 122,01 & 92,65 & 107,64 & 68,87 & 160,02 & 308,55 & 308,94 & 241,65 \\
November & 137,73 & 121,79 & 93,05 & 107,36 & 68,84 & 160,69 & 308,14 & 308,88 & 241,92 \\
December & 138,08 & 122,12 & 93,40 & 107,10 & 70,03 & 161,02 & 308,00 & 308,83 & 242,29 \\
\hline
\end{tabular}

\subsection{Correlation Coefficient $(\mathrm{Cc})$}

Pearson's correlation coefficient is a coefficient that shows the degree of linear similarities between two samples. It can be obtained as,

$$
C_{c}=\frac{E\left[\left(X-\mu_{x}\right)\left(Y-\mu_{y}\right)\right]}{\sigma_{x} \cdot \sigma_{y}}
$$

where correlation coefficient between variable $X$ and $Y$ (i.e. $C_{c}$ ), is obtained with respect to the expected value of the product between the difference of each variable with respect to its mean, $\mu_{x}$ or $\mu_{y}$, over the product of the standard deviation of two variables; i.e. $\sigma_{x}$ and $\sigma_{y}$. Since the expected value operator in the numerator of the fraction (i.e. Equation 2 ) is equal to the covariance between variable $X$ and $Y$, Equation 2 can also be rewritten as,

$$
C_{c}=\frac{\operatorname{Cov}(X, Y)}{\sigma_{x} \cdot \sigma_{y}}
$$

This coefficient changes between -1 to +1 whilst the negative and positive values respectively show the inverse and similar behavior between variables.

When the correlation coefficient is concerned, the variation of the groundwater levels at Deliçay (De), Adaköy (Ad), Yenice (Ye), and Kurşunlu (Ku) wells behave similarly to those of Narlıdere (Na) and it is possible that the Narlidere groundwater is recharged by the aquifers of those regions (Table 2 and Figure 3). In general, there are significant correlation coefficients between groundwater samples. The correlation coefficient between Narlidere (Na) and the Deliçay (De) is at its maximum for both wells. However, it is also important to notice that the time series of the Narlıdere (Na) has a high correlation coefficient with other wells time series except Karas1l (Ka) which has a high correlation with Kurşunlu $(\mathrm{Ku})$, most probably due to the northward flow direction. 
Table 2. The correlation matrix between the time series of the selected wells

\begin{tabular}{|c|c|c|c|c|c|c|c|c|c|}
\hline & Narlidere & Deliçay & Adaköy & Atıcilar & Yeniceabat & Çayırköy & Kurşunlu & Yenice & Karasıl \\
\hline Narlıdere & 1,00 & 0,72 & 0,71 & 0,51 & 0,57 & 0,31 & 0,65 & 0,71 & 0,15 \\
\hline Deliçay & & 1,00 & 0,36 & 0,31 & 0,50 & $-0,01$ & 0,69 & 0,41 & 0,19 \\
\hline Adaköy & & & 1,00 & 0,49 & 0,51 & 0,56 & 0,38 & 0,57 & 0,16 \\
\hline Atıcılar & & & & 1,00 & 0,31 & 0,19 & 0,41 & 0,43 & 0,01 \\
\hline Yeniceabat & & & & & 1,00 & 0,29 & 0,55 & 0,09 & 0,33 \\
\hline Çayırköy & & & & & & 1,00 & 0,05 & 0,12 & 0,41 \\
\hline Kurşunlu & & & & & & & 1,00 & 0,47 & 0,42 \\
\hline Yenice & & & & & & & & 1,00 & 0,06 \\
\hline Karasıl & & & & & & & & & 1,00 \\
\hline
\end{tabular}

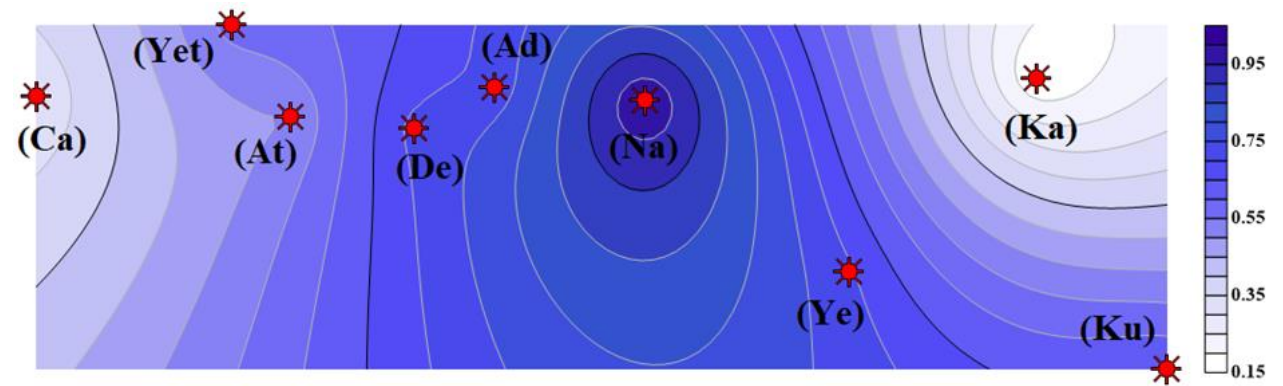

Figure 3. Coefficient of Correlation between time series of Narlıdere and other observation wells

More or less, it is hard to conclude that these correlations are an indication for direct and potential flow. However, it is still confident to say that the whole area and the aquifers are connected or affected by a similar resource. In this respect, Mount Uludağ is the first candidate that can play a major role in recharge and hydrology of the aquifers. Therefore, more investigations are needed to illuminate the unknowns.

\subsection{Coefficient of skewness (Cs)}

Coefficient of skewness is the $3^{\text {rd }}$ moment of the distribution and can be obtained once $n$ is equal to 3 in Equation 1. It shows the number of heavy tails in the distribution. That means, if this coefficient is positive, the lower values are observed more frequently whilst the negative value is an indication of higher values in the sample. Based on the analysis in Figure 4, the eastern and western parts of the Bursa are positively skewed. This means that, the northward and eastward flows are dominant flow directions in the region. These results are somehow in agreement with the obtained results in the previous section which suggests a northward flow direction. 


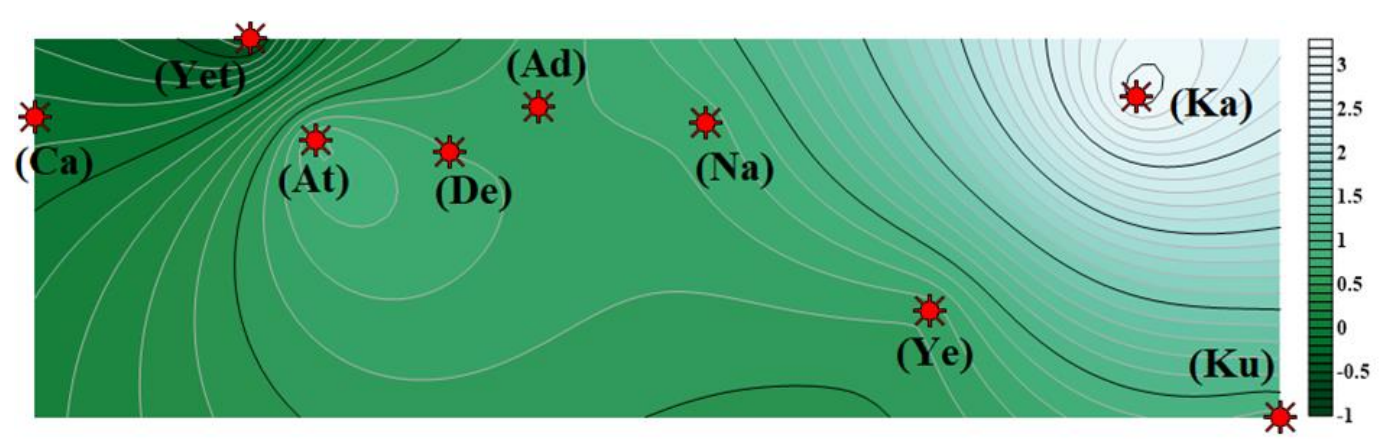

Figure 4. Coefficient of skewness (Cs) of groundwater level time series at selected wells

\subsection{Coefficient of Kurtosis $\left(C_{k}\right)$}

Coefficient of kurtosis is also used for further analysis. It shows how often the mean value occurs in the distribution (i.e. leptokurtic, mesokurtic, and platykurtic). This coefficient can be obtained as the $4^{\text {th }}$ moment of the distribution by assuming that the $n$ is equal to 4 in Equation 1. In this respect, Figure 5 shows the obtained results for this coefficient. Thus, a normally distributed data would have a kurtosis of 3, whilst higher values on the map show values in which are observed more frequently. This can also be interpreted as a stable situation in the groundwater level.

Based on this map, the northeast and north of the map experiences higher kurtosis whilst the lowest values occur in the southern parts. The low kurtosis can be interpreted as less reliability or the mean value of the sample occurs less frequently. Therefore, the north east of the map is experiencing more stable groundwater levels whilst the lowest values at the south could be a sign for the high permeability of the soil or a sign for subsurface- or groundwater-flow. This pattern in Yeniceabat (Yet) also shows less reliability which may be due to the low groundwater level that is disturbed by upstream and hillslope of the Mount Uludağ.

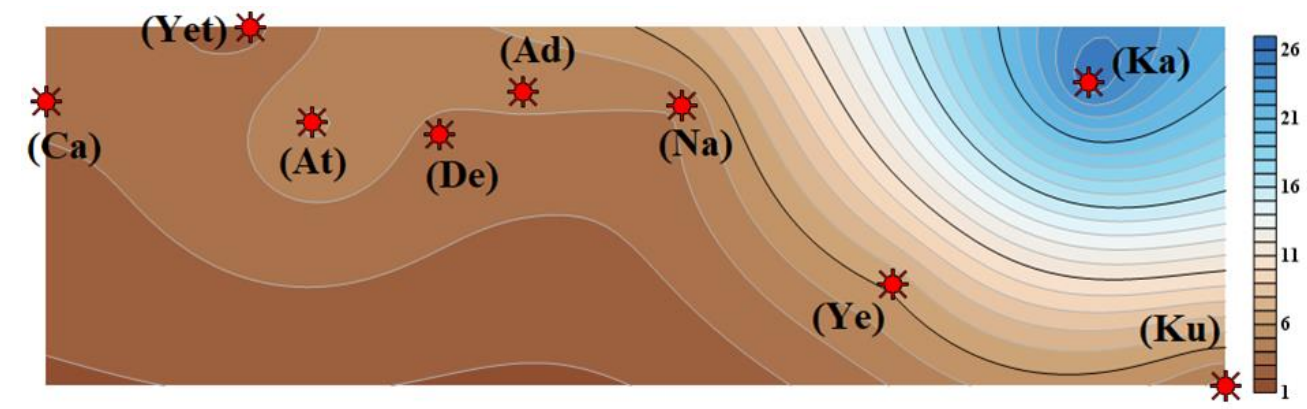

Figure 5. Coefficient of kurtosis (Ck) of groundwater level time series at selected wells 


\subsection{Coefficient of variation $\left(C_{v}\right)$}

Coefficient of variation is a statistical measure of which shows the degree of oscillation in the data. It can be calculated as,

$$
C_{v}=\frac{\sigma}{\mu}
$$

whilst the $\sigma$ and $\mu$ respectively are standard deviation and mean of the sample. It is a positive value which shows the relative standard deviation, a standardized measure of dispersion, or frequency in distribution.

The higher amounts of this coefficient are usually linked to the unstable behavior of a phenomenon, particularly when the groundwater level is oscillating frequently. It may also be a sign for groundwater interaction (i.e. recharge and/or discharge) with another resources. Hence, based on the projected results in Figure 6, Yenicabat (Yet) at the northwest of the region has the highest oscillation which is in agreement with the results obtained in Figures 2-4. The highest oscillations of the region initiate from the Deliçay (De) and extend to the north at Yeniceabat (Yet).

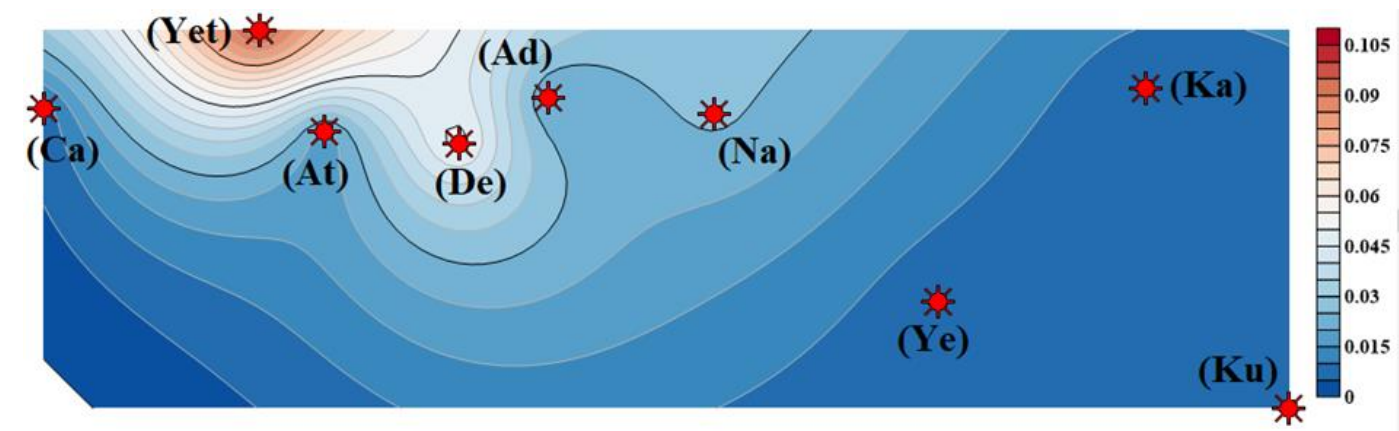

Figure 6. Coefficient of variation $(\mathrm{Cv})$ of groundwater level time series at selected wells

\section{Conclusion}

Groundwater is an important water resource which should be investigated around the world. In this study, several groundwater wells scattered around Bursa in Turkey are selected. Monthly groundwater level time series are obtained and statistical properties of these time series including mean, correlation coefficient, coefficient of skewness, coefficient of variation, and coefficient of kurtosis are used to project the groundwater level properties at the selected wells. It is concluded that;

i) the groundwater level time series at Deliçay, Adaköy, Yenice, and Kurşunlu wells behave similarly to the groundwater level at Narlidere. It is possible that the Narlidere groundwater level is recharged frequently by other aquifers of the region.

ii) Increases in groundwater levels at Narlıdere, Deliçay, Kurşunlu, and Yenice wells in late July could be compared with the decreases in groundwater levels in other wells at earlier months. It is estimated that the earlier decreases of the groundwater level are affected by the initiation of the irrigation season of the farmlands in the rural area. 
iii) the selected statistical patterns of $C_{v}, C_{s}$, and $C_{c}$, also suggests that Mount Uludağ has a major effect on the groundwater hydrology of the region. This is thought to be due to the snow melt at the Uludağ summit which causes a northward groundwater flow in the region.

It is noteworthy that the obtained results do not offer an ultimate solution for the groundwater situation in Bursa. In this respect, more investigations would be necessary to discover the flow direction and the major sources of the groundwater in the area.

\section{Acknowledgments}

Authors want to thank Bursa Regional Directorate of the State Hydraulic Works (i.e. State Hydraulic Works, DSI) for support in providing data and valuable information used in this study.

\section{References}

[1].UNESCO. (2006). Coping with Water Scarcity A Strategic Issue and Priority For Systemwide Action. fttp://ftp.fao.org/agl/aglw/docs/waterscarcity.pdf

[2] World Water Council. (2003). "Ministry of Foreign Affairs, Department of Regional and Transboundary Waters, General Directorate of State Hydraulic Works; Southeastern Anatolia Project Regional Development", Administration, Republic of Turkey.

[3] Charbeneau, R. J., 2000, “Groundwater Hydraulics and Pollutant Transport”. Prentice Hall, New Jersey, USA.

[4] Ustun, G. E., Akal Solmaz, S. K. (2004). "Yeraltı Suyu Potansiyelini Koruma, Kontrol Ve KurtarmaAmaçlı Alınabilecek Önlemler", I. Yeraltısuları Ulusal Sempozyumu 23-24 Aralık, Konya.

[5] Imbach, T. (1997). Deep Groundwater Circulation in the tectonically active area of Bursa, Northwest Anatolia, Turkey. Geothermics, 26(2), Pp 251-278.

[6] Balderer, W., Greber, E., Imbach, T., Rauert, W., Trimborn, P., \& Guler, S. (1992). Environmental isotope study of thermal, mineral and normal groundwater within the Bursa and Kuzuluk/Adapazari areas of northwestern Turkey. In Isotope techniques in water resources development 1991.

[7] Gundogdu, K. S., Guney, I. (2007). Spatial analyses of groundwater levels using universal kriging. Journal of earth system science, 116(1), 49-55.

[8] Adamowski, J., Chan, H. F. (2011). A wavelet neural network conjunction model for groundwater level forecasting. Journal of Hydrology, 407(1-4), 28-40.

[9] Vaheddoost, B., Aksoy, H. (2018). Interaction of groundwater with Lake Urmia in Iran. Hydrological processes, 32(21), 3283-3295.

[10] Hao, Z., Zhao, H., Zhang, C., Zhou, H., Zhao, H., \& Wang, H. (2019). Correlation Analysis Between Groundwater Decline Trend and Human-Induced Factors in Bashang Region. Water, 11(3), 473. 